\title{
Attenuation of Human Immunodeficiency Virus Type 1 Cytopathic Effects by Replacing a 424-bp Region of Envelope from a Noncytopathic Biological Clone
}

\author{
SERENE E. FORTE, MOHAN SOMASUNDARAN, and JOHN L. SULLIVAN
}

\begin{abstract}
We analyzed the $e n v$ genes of cytopathic and noncytopath ic biological clones derived from two HIV-1-infected children with discordant clinical courses. Chimeric viruses were constructed by switching env regions from V2 through V3 of the biological clones with the corresponding region from the molecular clone NL4-3. These HIV-1 chimeric viruses exhibited similar replication kinetics as well as syncytium-inducing abilities. The chimeric virus containing the env region of noncytopath ic biological clone, GC6 8-4, was noncytopathic in an in vitro cell-killing assay, while the chimeric virus containing the env region of cytopathic biological clone, HC4, was cytopathic in the in vitro cell-killing assay. These studies suggest the presence of a cytopathicity determinant that maps to the envelope sequences contained within the downstream region of $\mathrm{V} 2$ and within the V3 region (nucleotide position 6822 to nucleotide position 7250, based on NL4-3 sequence).
\end{abstract}

\section{INTRODUCTION}

$\mathrm{T}$ HE ENTRY of human immunodeficie ncy virus type 1 (HIV1) into cells is mediated by the envelope glycoprotein. HIV 1 strains differ in their ability to infect specific cell types and can be characterized in vitro according to their ability to replicate in macrophages and established T-cell lines as well as by their ability to induce cytopathic effects. Two groups of isolates have been described: those that are capable of replicating in established $\mathrm{T}$-cell lines ( $\mathrm{T}$-cell tropic) and those that infect primary macrophages (M-topic). T-cell tropic isolates replicate more rapidly and to higher levels in primary lymphocytes (rapid/high) than M-tropic isolates, which replicate slowly and to lower levels in primary lymphocytes (slow/low). ${ }^{1-4}$ Many isolates that infect $\mathrm{T}$ cells are able to induce syncytia and are termed syncytium-induc ing (SI), whereas most M-tropic isolates are non-syncytium-inducing (NSI).

Recently, new discoveries have shown that chemokine receptors are important cofactors for entry of HIV-1 into cells. ${ }^{5}$ CXCR4 mediates viral entry into CD4-positive T-cell lines and CCR5 mediates entry into macrophages. ${ }^{6-10}$ Dual tropic HIV1 strains have been identified that can use either one of these receptors to gain entry into cells. ${ }^{6,8}$

The hallmark of HIV-1 infection is the progressive destruction of CD4 $\mathrm{T}$ cells in vivo. ${ }^{11,12}$ Macrophage tropic NSI iso- lates are preferentially transmitted and are present throughout the length of infection. ${ }^{13-15}$ The emergence of T-cell tropic SI isolates correlates with the decrease of CD4 lymphocytes and progression of HIV-1 infection to AIDS. ${ }^{4,16}$ However, this switch to T-cell tropic SI isolates is not necessary for T-cell depletion and progression to AIDS, especially in vertical HIV-1 infection. ${ }^{17,18}$

There is no clear correlation between when an infant is infected and disease progression. It has been reported that an association exists between in utero infection, high viral load in the early neonatal period, and rapid disease progression. ${ }^{19}$ However, plasma RNA levels in infants infected in utero or in the intrapartum period are not easily separable. While it is true that most infants with high viral burdens will exhibit disease progression, we have followed vertically infected children for several years with extremely high viral loads and normal CD4 counts. ${ }^{17,18}$ While disease progression following vertical infection may be variable with observable differences in the occurrence of illness and survival times,${ }^{20}$ by and large vertically infected children experience a more rapid clinical course than adults. A number of factors are likely to be responsible for the observed variability in clinical course. These include the route of perinatal HIV-1 transmission, ${ }^{21}$ the viral burden, ${ }^{22,23}$ the biological phenotype, ${ }^{15,24-26}$ and host factors including both cellular and humoral immune responses. ${ }^{27-29}$ 
The molecular mechanism(s) of HIV-1-induced cell lysis remains unclear and is likely to be multifactorial. Differences in HIV-1 viral tropism, phenotype, and replication kinetics have been assigned to the envelope surface glycoprotein. ${ }^{30,31}$ Along with these properties, studies of mutant HIV-1 viruses have provided evidence that a major determinant for single cell killing maps to the viral envelope glycoproteins. ${ }^{32-34} \mathrm{Cao}$ et al. ${ }^{35} \mathrm{de}-$ scribed an inducible system to examine envelope-media ted single cell lysis. Their studies demonstrated that the ability of HIV1 envelope glycoproteins to mediate membrane fusion was obligatory for both syncytium formation and single cell lysis.

Previously, we described functional HIV-1 biological clones that were isolated from two infected children with high viral loads in vivo ${ }^{18}$ who had discordant clinical courses. The absolute CD4 cell counts of HIV-1-seroposi tive pediatric patients $\mathrm{A}$ and $\mathrm{D}$, at the time of virus isolation, were 2312 and 64 counts $/ \mathrm{mm},{ }^{3}$ respectively. The primary HIV-1 isolate, A, obtained from patient A at 47 months of age, was NSI and HIV1 isolate, D, obtained from patient D at 36 months of age, was SI. Patient D has subsequently succumbed to AIDS, while patient A remained asymptomatic (and is currently on combination antiretroviral therapy). Multiple biological clones were obtained from HIV-1 isolates A and D. All the biological clones from isolate A were NSI and all the biological clones from isolate D were SI in MT-2 cells. Representative biological clones, GC6 8-4 (derived from isolate A obtained from patient A) and HC4 (derived from isolate D obtained from patient D) grew to the highest titer and were selected for further characterization. ${ }^{18}$ These clones exhibited similar replication kinetics but differed in syncytium-induc ing ability: biological clones GC6 8-4 and $\mathrm{HC} 4$ are NSI and SI, respectively. Furthermore, the biological clones GC6 8-4 and HC4 differed markedly in in vitro cellkilling assays: GC6 8-4 was noncytopathic and HC4 was cytopathic. ${ }^{18}$

To assess the relationship between envelope gene sequences and cell killing, we analyzed the envelope gene of biological clones GC6 8-4 and HC4. Chimeric viruses were constructed by switching the envelope sequences contained within the downstream region of $\mathrm{V} 2$ and within the $\mathrm{V} 3$ region of each of the biological clones with the corresponding region from the molecular clone NL4-3. These chimeric viruses exhibited similar replication kinetics as well as syncytium-indu cing abilities. The only difference was in their ability to induce cell killing. These studies provide evidence that in certain viral variants, HIV-1-induced cytopathicity maps to the envelope sequences contained within the downstream region of V2 and within the V3 region (StuI at position 6822 to NheI at position 7250 based on NL4-3 nucleic acid sequence ${ }^{36}$ ).

\section{MATERIALS AND METHODS}

\section{Patients}

Patient A was clinically asymptomatic when the virus was isolated and remains so 7 years later. At the time of viral isolation, patient $\mathrm{A}$ was 47 months old, with normal CD4 counts of $2312 / \mathrm{mm} .{ }^{3}$ Unexpectedly, peripheral viremia in this child was very high as determined by serum HIV-1 p24 antigen levels $(1773 \mathrm{pg} / \mathrm{ml})$ and by plasma viral RNA copies $(280,000 / \mathrm{ml})$.
Since the original viral isolate was obtained, Patient A has maintained normal CD4 T-cell numbers and is currently on combination antiretroviral therapy. Patient D had AIDS at the time of viral isolation. The child was 36 months old with very low CD4 $\mathrm{T}$ cell counts $\left(64 / \mathrm{mm}^{3}\right) .{ }^{18}$

\section{Virus culture}

Peripheral blood mononuclear cells (PBMC) from seronegative individuals were infected with biological clones, GC6 84 and HC4. ${ }^{18}$ On days 3 and 5 of viral infection, culture supernatants were monitored for HIV-1 p24 antigen production by ELISA. On day 5 postinfection, $10^{7}$ cells were harvested and genomic DNA was extracted.

\section{DNA isolation}

PBMC $\left(10^{7}\right)$ from cultures infected with biological clones, GC6 8-4 and HC4, were pelleted and washed twice with phosphate-buffered saline (PBS). Genomic DNA was prepared by resuspending the cell pellets in $5 \mathrm{ml}$ lysis buffer $(10 \mathrm{mM}$ Tris- $\mathrm{HCl}, 400 \mathrm{mM} \mathrm{NaCl}, 2 \mathrm{mM}$ EDTA, $\mathrm{pH}$ 8.2) to which sodium dodecyl sulfate (SDS) (final concentration $0.7 \%$ ) and proteinase $\mathrm{K}(1.7 \mathrm{mg})$ were added. The genomic DNA preparation was incubated at $37^{\circ} \mathrm{C}$ overnight. Following this incubation, $1.6 \mathrm{ml}$ saturated $\mathrm{NaCl}$ was added, mixed, and centrifuged at $2500 \mathrm{rpm}$ for $15 \mathrm{~min}$. To the supernatant, $7 \mathrm{ml}$ of isopropanol was added to precipitate the DNA. The DNA was pelleted by centrifugation, resuspended in $30 \mu \mathrm{TE}$, and stored at $-20^{\circ} \mathrm{C}$.

\section{PCR amplification of env region}

Approximately $200 \mathrm{ng}$ of genomic DNA was used as a template for amplification of a 3.0-kb product of HIV-1 proviral sequence containing the entire coding region for gp160. The reaction mixture contained $10 \mu \mathrm{l}$ GeneAmp PCR Buffer II (50 $\mathrm{mM} \mathrm{KCl}, 10 \mathrm{mM}$ Tris- $\mathrm{HCl}) ; 2.5 \mathrm{mM} \mathrm{MgCl}_{2} ; 200 \mu \mathrm{M}$ each of dATP, dCTP, dGTP, and dTTP; 10 pmol each of primer I5-1 (5'-CAGAATTGGGTGTCGACATAGCAG-3') and MN12 (5'-CACTTGCCACCCATCTTATAGGAAAA TCCTTTCCAAGCC-3') in a final volume of $90 \mu \mathrm{l}$. Primers I5-1 and MN12 anneal at positions 5774-5797 and 8762-8801, respectively, based on published NL4-3 nucleotide positions. ${ }^{36}$ Polymerase chain reactions (PCR) were completed in an automated PerkinElmer (GeneAmp 9600) thermal cycler programmed for the following: denaturation at $94^{\circ} \mathrm{C}$ for $3 \mathrm{~min}$, followed by the addition of Perkin Elmer AmpliTaq $(2.5 \mathrm{U}$ in $10 \mu \mathrm{l})$ during $87^{\circ} \mathrm{C}$ hold ("hot start"). The reactions were subjected to 30 cycles at $94^{\circ} \mathrm{C}$ for $1 \mathrm{~min}, 55^{\circ} \mathrm{C}$ for $1.5 \mathrm{~min}$, and $72^{\circ} \mathrm{C}$ for $3 \mathrm{~min}$. A final extension step at $72^{\circ} \mathrm{C}$ for $10 \mathrm{~min}$ was added after the last amplification cycle.

\section{Molecular cloning of env region into an expression vector}

To screen for the appropriate sized amplicon, $10 \mu \mathrm{l}$ of the final PCR amplification was resolved by electrophoresis on a $0.8 \%$ agarose gel. The remaining $90 \mu \mathrm{l}$ of the reaction was phenol-chloroform extracted, ethanol precipitated, resuspended in $15 \mu \mathrm{l}$ of water, and resolved by electrophoresis on a $0.8 \%$ agarose gel. The 3-kb DNA fragment was excised from the gel, 
purified by Elu-Quick (Schleicher \& Schuell, Keene, NH), resuspended in water, and stored at $-20^{\circ} \mathrm{C}$ until further use. The purified product was ligated into pBluescript (Stratagene, La Jolla, CA) and $10 \mu \mathrm{l}$ of the ligation reaction was used to transform DH5 $\alpha$ bacterial cells. Transformed colonies were color selected on ampicillin, IPTG (isopropyl- $\beta$-D-thiogalactopyranoside), $\mathrm{X}$-gal (5-bromo-4-chlo ro-3-indoyl- $\beta$-D-galactopyranoside) plates. White colonies were chosen and amplified in culture. Minipreps were performed from the overnight cultures. The miniprep DNA was screened for the appropriate sized insert by restriction digest and electrophoresis on a $0.8 \%$ agarose gel.

\section{DNA sequencing of full length env region}

The double-stranded plasmid DNA was sequenced in both the forward and reverse directions with primers that spanned the entire env regions overlapping every $200 \mathrm{bps}$ (primer sequences available upon request). Of double-stranded DNA template $1 \mu \mathrm{g} / \mu \mathrm{l}$ was added to $8 \mu \mathrm{l}$ terminator premix (A-dye terminator, $\mathrm{C}$-dye terminator, $\mathrm{G}$-dye terminator, $\mathrm{T}$-dye terminator, dITP, dATP, dCTP, dTTP, Tris-HC1, $\mathrm{pH} 9.0, \mathrm{MgC1}_{2}$, thermal stable pyrophosphatase, and AmpliTaq DNA polymerase FS), $10 \mathrm{pmol}$ of primer, and water to a final volume of $20 \mu \mathrm{l}$. DNA sequencing was performed in an automated Perkin-Elmer thermal cycler (GeneAmp 9600) programmed for 30 cycles of denaturation at $94^{\circ} \mathrm{C}$ for $1 \mathrm{~min}$, primer annealing at $55^{\circ} \mathrm{C}$ for 1.5 min, and extension at $72^{\circ} \mathrm{C}$ for $3 \mathrm{~min}$. The reaction mixture was ethanol precipitated to remove unincorporated deoxynucleoside triphosphate and oligonucleotides, and then vacuum dried. The dye-deoxy-labeled sequencing reaction mixes were resolved by electrophoresis on a $6 \%$ polyacrylamide gel and analyzed with an automated DNA sequenator (model 373A, Applied Biosystem, Inc., Foster City, CA). Individual sequences were assembled by using the Sequencher program (Gene Codes Corp, Ann Arbor, MI). Sequences were determined for both strands of DNA and were aligned by the methods of Lamers et al. ${ }^{37}$ at Gene Genie, Inc (Thibodaux, LA).

\section{Plasmids}

Plasmid pNL4-3, containing a chimeric HIV-1 provirus, was obtained from the AIDS Research and Reference Reagent Program, Rockland, MD. The subclones, p83-2 and p83-10, the 5' and $3^{\prime}$ half of NL4-3, respectively, were kindly provided by R. Desrosiers. ${ }^{38}$

\section{PCR of the StuI to NheI region of env}

Since GC6 8-4 and HC4 envelope sequence lack the $\mathrm{NHeI}$ sites but contain the $S t u \mathrm{I}$ sites, this region was obtained by means of PCR with StuI primer (5'-ATTACAC CAGGTA-3') and NheI primer (3'-TTCTCTTAATTTGCTAGCTATCTG-5'). Approximately $200 \mathrm{ng}$ of DNA was used as a template for amplification of a 424-bp product of HIV-1 env sequence contained within the downstream region of $\mathrm{V} 2$ and within the $\mathrm{V} 3$ region. The reaction mixture contained $10 \mu \mathrm{l} \mathrm{Ge}$ neAmp PCR Buffer II (50 mM KCl, 10 mM Tris-HCl, pH 8.3), $2.5 \mathrm{mM} \mathrm{MgCl}_{2}, 200 \mu \mathrm{M}$ each of dATP, dCTP, dGTP, and dTTP, and 10 pmol each of primer, in a final volume of $90 \mu \mathrm{l}$. "Hot start" PCR reactions were completed in an automated Perkin-
Elmer (GeneAmp 9600) thermal cycler programmed for denaturation at $94^{\circ} \mathrm{C}$ for $3 \mathrm{~min}$, followed by the addition of AmpliTaq $(2.5 \mathrm{U}$ in $10 \mu \mathrm{l})$ during $87^{\circ} \mathrm{C}$ hold. The reaction mixtures were subjected to 30 cycles at $94^{\circ} \mathrm{C}$ for $1 \mathrm{~min}, 55^{\circ} \mathrm{C}$ for $1.5 \mathrm{~min}$, and $72^{\circ} \mathrm{C}$ for $3 \mathrm{~min}$. A final extension step at $72^{\circ} \mathrm{C}$ for $10 \mathrm{~min}$ was added after the last amplification cycle.

\section{Molecular cloning of NL4-3 chimeric constructs, p83-SFG and p83-SFH}

From the PCR reaction $10 \mu \mathrm{l}$ was resolved by electrophoresis on a $1 \%$ agarose gel to screen for the appropriate molecular weight amplicon. The remaining $90 \mu \mathrm{l}$ of the PCR reaction mixture was ethanol precipitated and resuspended in $15 \mu \mathrm{l}$ of water and stored at $-20^{\circ} \mathrm{C}$. The 424-bp DNA fragment was gel purified by Elu-Quick, phenol-chlorofor m extracted, ethanol precipitated, and resuspended in water. The purified product was cloned into p83-10 $0^{38}$ by appropriate restriction sites (StuI at position 6822 and NheI at position 7250 based on published NL4-3 nucleotide sequence). ${ }^{38}$ Aliquots $(10 \mu \mathrm{l})$ of the ligation product was used to transform competent DH $5 \alpha$ bacterial cells. Colonies were chosen at random and amplified overnight in $5 \mathrm{ml} \mathrm{LB}$ broth containing ampicillin. A small scale plasmid preparation was performed to recover DNA. Of the plasmid preparation $10 \mu \mathrm{l}$ was digested with appropriate restriction endonuclease, and the presence of an insert was screened by electrophoretic resolution on a $1 \%$ agarose gel.

\section{Cell culture}

$\mathrm{CEM} \times 174$ cells and Jurkat cells were maintained in medium containing RPMI-1640 (GIBCO Laboratories, Grand Island, NY) supplemented with $10 \%$ fetal calf serum (FCS) (GIBCO Laboratories, Grand Island, NY). Jurkat-CCR5 cells (kindly provided by M. Emerman) were maintained in RPMI-1640/10\% FCS containing $0.2 \mu \mathrm{g} / \mathrm{ml}$ of puromycin. PBMC and CD4 $\mathrm{T}$ cells were cultured at $2 \times 10^{6}$ cells $/ \mathrm{ml}$ in RPMI-1640/10\% FCS containing 10 units $/ \mathrm{ml}$ of recombinant human interleukin2 (Boehringer-M annheim, Indianapolis, IN).

\section{Transfections}

Transfections were carried out following the procedure described by Gibbs et al. ${ }^{38}$ Briefly, just prior to transfection, $3 \mu \mathrm{g}$ of DNA was added stepwise in five aliquots with gentle vortexing to $1.4 \mathrm{ml}$ of Dulbecco modified Eagle medium (DMEM) DEAEDextran solution (DMEM containing $125 \mu \mathrm{g} / \mathrm{ml}$ of DEAEDextran in $50 \mathrm{mM}$ Tris, $\mathrm{pH}$ 7.3). In a $15-\mathrm{ml}$ conical tube, $6 \mathrm{ml}$ of $\mathrm{CEM} \times 174$ was pelleted containing $0.5-0.8 \times 10^{6}$ cells $/ \mathrm{ml}$, which were split the night prior. The cells were washed twice with $5 \mathrm{ml}$ of serum-free DMEM and resuspended in $1.4 \mathrm{ml}$ of DNA-DMEM-DEAE-Dextran solution. The cell DNA-DMEM mixture was incubated at $37^{\circ} \mathrm{C}$ for $1 \mathrm{~h}$. After incubation, the cells were pelleted and washed with $5 \mathrm{ml}$ serum-free DMEM. Cells were resuspended in $6 \mathrm{ml}$ RPMI-1640/10\% FCS and incubated at $37^{\circ} \mathrm{C}$. Supernatant p 24 antigen activity was monitored every 2-3 days. Cells were split as needed 1:2 or 1:3 twice weekly.

\section{Viral phenotype of HIV-1 chimeric viruses}

Chimeric viruses (SF-G 1, 3, 4, 5 and SF-H 2, 3, 4, 5) were phenotyped on MT-2 cells for their ability to replicate and form 
A) V1-V2

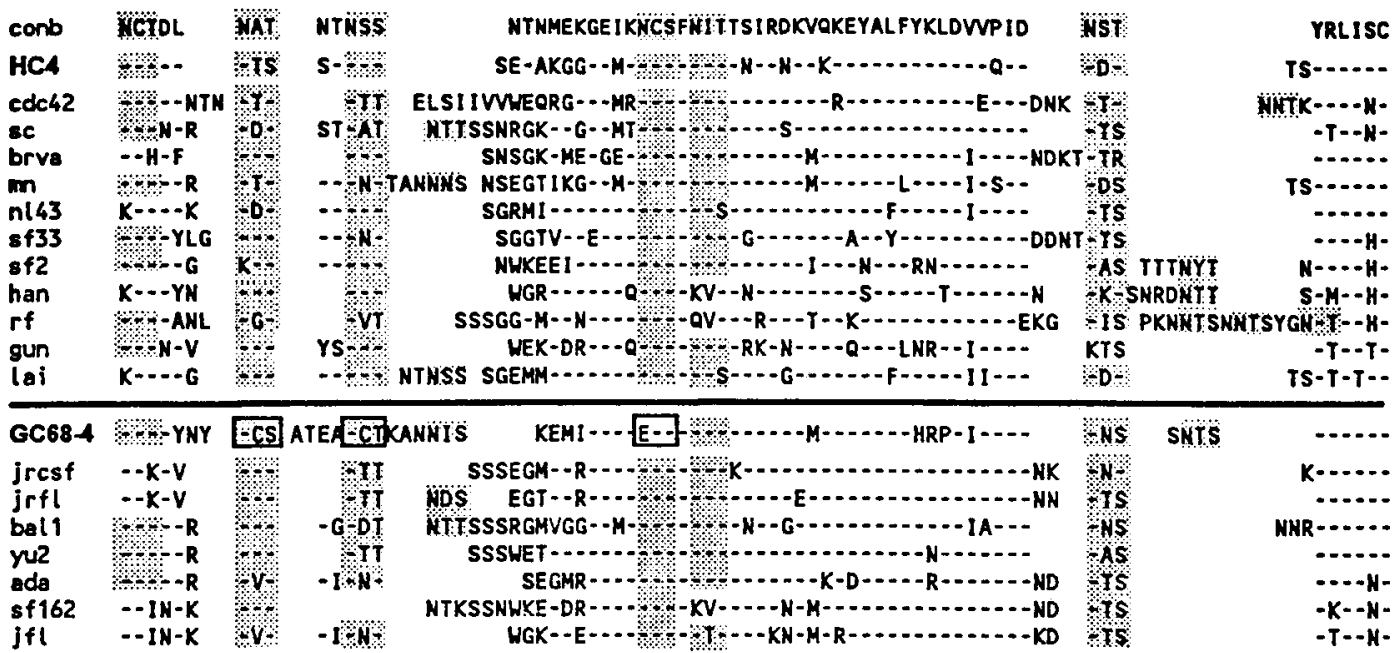

B) V3

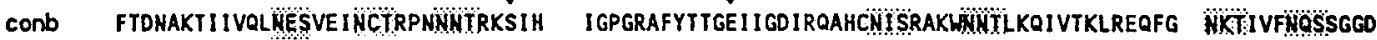

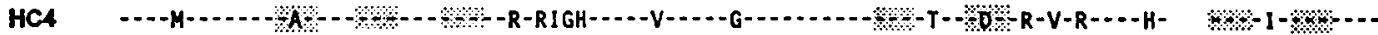
Cdc42 - -N - . .

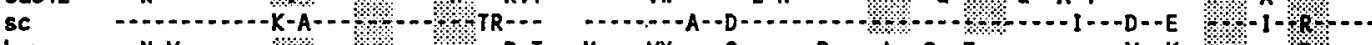

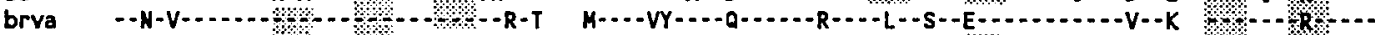

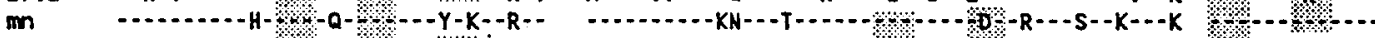

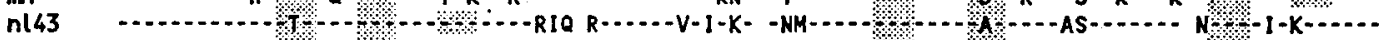

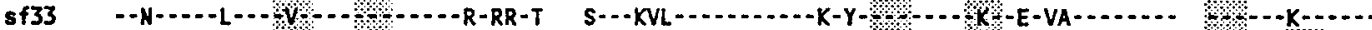

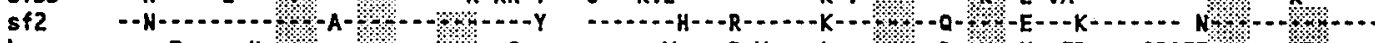

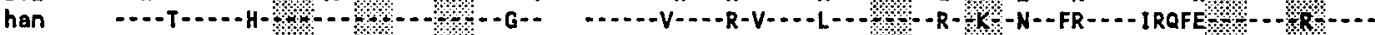

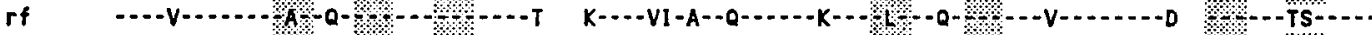

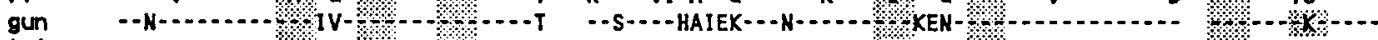

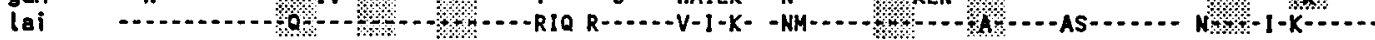

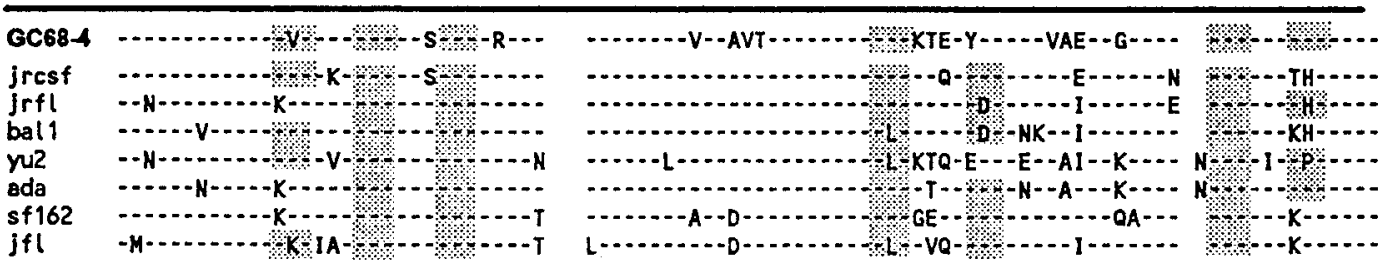

\section{C) V4-V5}

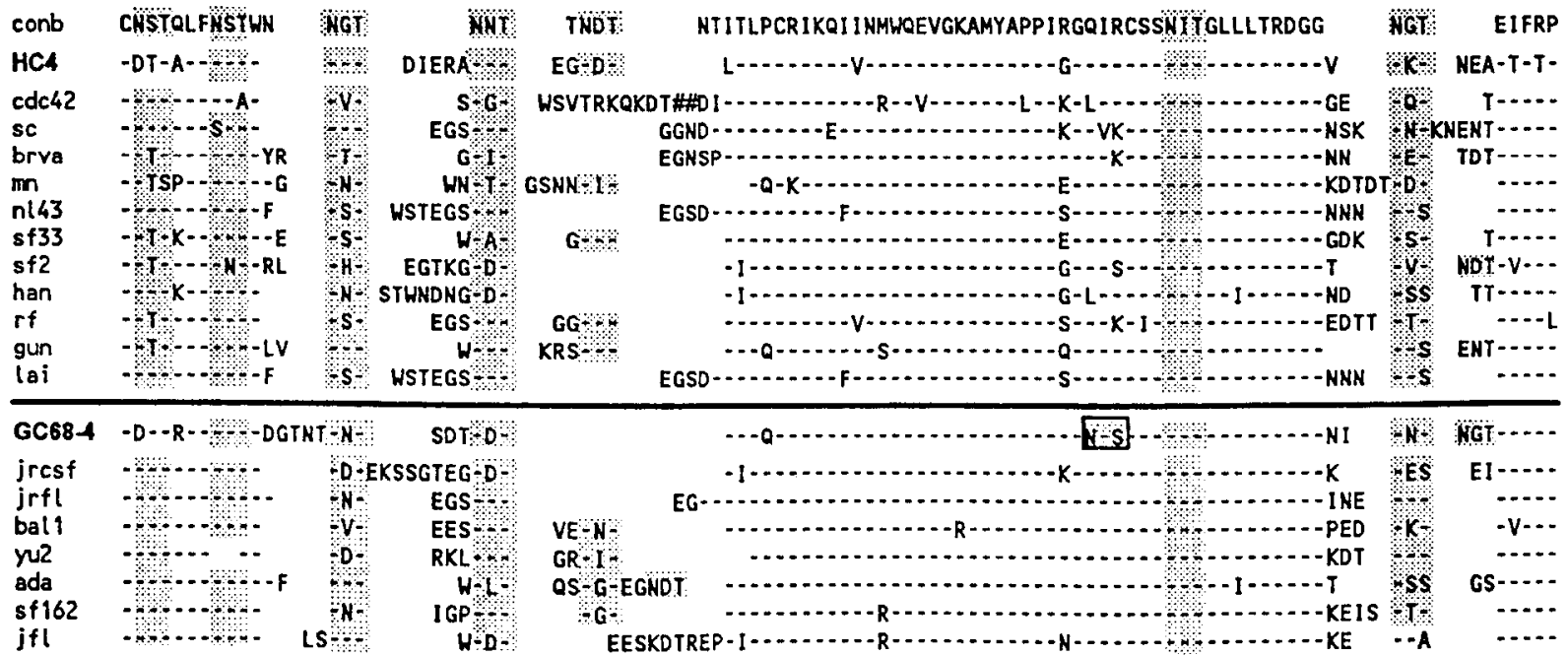


syncytia following a previously published protocol. ${ }^{39}$ The protocol was modified to determine viral replication in MT-2 cells using antigen capture ELISA to measure HIV-1 p24 gag protein in cell-free supernatants. ${ }^{17}$ Similarly, chimeric viruses were phenotyped on Jurkat cells and Jurkat-CCR5 cells for their ability to form syncytia and to replicate.

\section{Infection of Jurkat-CCR5 cells with chimeric viruses, $S F-G 1$ and $S F-H 2$}

Since both SF-G1 and SF-H2 chimeric viruses infected and replicated in Jurkat-CCR5 $\mathrm{T}$ cells and not in Jurkat $\mathrm{T}$ cells, Jurkat-CCR 5 cells were infected with HIV-1 chimeric viruses according to previously described methods. ${ }^{18} \mathrm{HIV}-1$ infected and uninfected Jurkat-CCR5 cells were cultured at $0.5 \times 10^{6}$ cells/ml in RPMI-1640/10\% FCS containing $0.2 \mu \mathrm{g} / \mathrm{ml}$ of puromycin.

\section{Infection of primary PBMC with $H I V-1$ chimeric viruses}

Of viral p24 from chimeric viruses obtained by transfections 50 $\mathrm{ng} / \mathrm{ml}$ was used to infect PBMC. Briefly, normal PBMC from HIV-1-seronegative donors were phytohem agglutinin (PHA) stimulated for 3 days and infected with HIV-1 chimeric viruses, SF-G1 and SF-H2, according to previously described methods. ${ }^{18} \mathrm{HIV}-1$-infected and uninfected PBMC were cultured at $2 \times 10^{6}$ cells $/ \mathrm{ml}$ in RPMI-1640/10\% FCS containing 10 units/ml of recombinant human interleukin-2.

\section{Depletion of CD8 $T$ cells}

PBMC were isolated by Ficoll density and CD8 T cells were depleted using anti-CD8 antibody-coated magnetic beads (Dynal, Inc., Lake Success, NY) according to manufacturer's protocol. The supernatant containing CD4 T cells was centrifuged and the cell pellet was resuspended in RPMI-1640/10\% FCS with 10 units/ml of interleukin-2.

\section{Infection of CD4 T cells with HIV-1 chimeric viruses, $S F-G 1$ and $S F-H 2$}

CD4 $\mathrm{T}$ cells were PHA stimulated overnight and infected with HIV-1 chimeric viruses, SF-G1 and SF-H2, according to previously described methods. ${ }^{18} \mathrm{HIV}$-1-infected and uninfected CD4 $\mathrm{T}$ cells were cultured at $2 \times 10^{6}$ cells $/ \mathrm{ml}$ in RPMI$1640 / 10 \%$ FCS with 10 units/ml of interleukin-2.

\section{Assessment of HIV-1-induced cytopathic effects}

HIV-1-induced cytopathic effects by the chimeric viruses, SFG1 and SF-H2, were determined by evaluating cell viability using trypan blue dye exclusion.
Measurement of cell surface CD4 and CD8 expression

Cell surface CD4 and CD8 expression was measured by flow cytometry. Briefly, $10^{7}$ cells from either infected or uninfected T-cell cultures were washed with cold PBS containing $1 \%$ azide and incubated for $30 \mathrm{~min}$ on ice with a mixture of fluoresceinlabeled anti-CD 4 monoclonal antibody and phycoerythrin-labeled anti-CD8 monoclonal antibody (Becton-Dickinson, San Jose, CA). The cells were washed with PBS containing $1 \%$ azide and fixed for $10 \mathrm{~min}$ in $0.2 \%$ paraformaldehyde in PBS and analyzed by FACscan flow cytometer (Becton-Dickinson, San Jose, CA). Phycoerythrin- and fluorescein-labele d mouse gamma-globulins were used as negative stains for controls.

\section{Determination of HIV-1 proviral copies}

To determine the number of proviral copies of HIV-1 viral DNA, PCR was performed on lysates of serially diluted CD4 $\mathrm{T}$ cells infected with chimeric viruses, SF-G1 and SF-H2, using the Roche Amplicor HIV-1 test kit following the previously published method. ${ }^{40}$ Briefly, a region of HIV-1 gag gene was amplified using biotinylated SK431/SK462 primer pairs in an automated Perkin Elmer (GeneAmp 9600) thermocycler. The cycling parameters were as follows: five cycles of denaturation at $95^{\circ} \mathrm{C}$ for $10 \mathrm{sec}$, annealing at $55^{\circ} \mathrm{C}$ for $10 \mathrm{sec}$, and extension at $72^{\circ} \mathrm{C}$ for $10 \mathrm{sec}$; followed by 30 cycles of denaturation at $90^{\circ} \mathrm{C}$ for $10 \mathrm{sec}$, annealing at $60^{\circ} \mathrm{C}$ for $10 \mathrm{sec}$, and extension at $72^{\circ} \mathrm{C}$ for $10 \mathrm{sec}$, and an additional extension at $72^{\circ} \mathrm{C}$ for 5 min. The amplicons were captured in wells coated with the probe and detected by ELISA using avidin-conjugated horseradish peroxidase as a secondary marker.

\section{Measurement of viral replication}

To measure HIV-1 replication in infected PBMC, JurkatCCR5 cells, and CD4 T-cell cultures, cell-free culture supernatants were assayed for HIV-1 p24 gag protein using an antigen capture ELISA.

\section{RESULTS}

\section{Derivation of HIV-1 biological clones and chimeric viruses}

The derivation of HIV-1 biological clones and NL4-3 chimeric viruses from viral isolates obtained from patients $\mathrm{A}$ and $\mathrm{D}$ are delineated below:

Patient $\boldsymbol{A} \rightarrow$ isolate $\mathrm{A} \rightarrow$ clone GC6 8-4 $\rightarrow$ chimeric GC684/NL4-3 (SF-G1)

Patient $\boldsymbol{D} \rightarrow$ isolate $\mathbf{D} \rightarrow$ clone $\mathbf{H C 4} \rightarrow$ chimeric HC4/NL4-3 (SF-H2)

FIG. 1. Alignment of variable regions of the envelope gene of HIV-1 biological clones, GC6 8-4 and HC4, and T-cell and macrophage tropic viruses. (A) Alignment of env V1/V2 T-cell tropic (top) and macrophage tropic (bottom) viruses. (B) Alignment of V3 T-cell tropic (top) and macrophage tropic (bottom) viruses. (C) Alignment of env V4/V5 T-cell tropic (top) and macrophage tropic (bottom) viruses. The highlighted regions show the potential N-linked glycosylation sites within the variable region of the envelope protein. GC6 8-4 has lost two potential N-linked glycosylation sites within V1/V2, one in V3 and two within V4/V5 regions. The sequences derived from HC4 and GC6 8-4 clearly align with the published SI and NSI viral sequences, respectively. This is in agreement with our phenotypic assignment of HC4 as an SI virus, and GC6 8-4 as an NSI virus. 


\section{Env sequences from HIV-1 biological clones}

Figure 1 shows the variable regions (V1-V5) from HIV-1 biological clones, HC4 and GC6 8-4, aligned to SI/T-cell tropic and NSI/macrophage tropic viruses, respectively. HIV-1 biological clone, GC6 8-4, has lost two potential N-glycosylation sites within $\mathrm{V} 1-\mathrm{V} 2$, one in $\mathrm{V} 3$ and two within $\mathrm{V} 4-\mathrm{V} 5$ regions.

The V3 region derived from $\mathrm{HC} 4$ clearly aligns with published SI viral sequences. This is in agreement with our phenotypic assignment of $\mathrm{HC} 4$ as an SI virus. Similarly, the V3 region of GC6 8-4 aligns with published NSI viral sequences and agrees with our assessment of GC6 8-4 as an NSI virus. ${ }^{18}$

\section{$V 3$ sequences determined from chimeric viruses}

Zhong et al. ${ }^{41}$ and others ${ }^{42}$ have shown a correlation between overall amino acid change and the phenotype of HIV-1 viruses. V3 loops of SI and NSI variants generally have an overall charge of ${ }^{+} 5$ and ${ }^{+} 3$, respectively. Moreover, T-cell tropic SI viruses generally have a basic amino acid at one or more of the following positions: $11,24,25$, and 32 (numbering from the first cysteine of V3). Macrophage tropic NSI viruses have either an acidic amino acid or alanine at position 25 . The third variable region of envelope sequenced from HIV-1 chimeric viruses SF-G1 and SF-H2 are 35 and 38 amino acids in length, respectively (Fig. 1B). The V3 region from HIV-1 chimeric virus SF-H2 carries an overall charge of ${ }^{+} 7$ with a basic amino acid located at position 11 of the V3 loop (Fig. 1B). Zhong and colleagues ${ }^{41}$ report that a switch to arginine at position 11 along with a switch to glycine at position 25 coincides with a change from NSI to SI phenotype. The V3 region from HIV-1 chimeric virus SF-H2 has these changes (Fig. 1B). The V3 region from HIV-1 chimeric virus SF-G1 carries an overall charge of ${ }^{+} 5$ with an alanine at position 25 of the V3 loop (Fig. 1B).

\section{Phenotype of chimeric viruses}

Chimeric viruses were made by removing the region from StuI (nucleotide 6822) to NheI (nucleotide 7250) from pNL43 and replacing it with the corresponding region from each biological clone (Fig. 2A). To assess if the switch in regions from

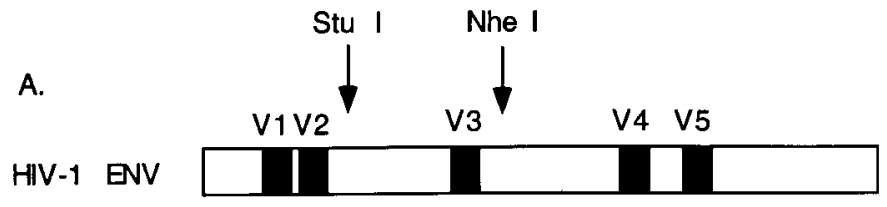

NL4-3

HC4

GC6 8-4

SF-H2

SF-G1
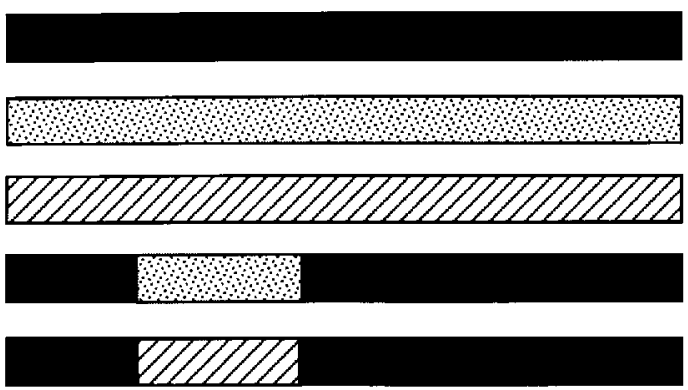

c.

$\begin{array}{lcc}\frac{T}{2 \text { cells/PBMC }} & \text { Phenotype\# } & \text { Cytopathic*+ } \\ +++1+++ & \text { SI } & \text { CP } \\ +++1+++ & \text { SI } & \text { C? } \\ -1+++ & \text { NSI } & \text { NCP } \\ +++1++ & \text { SI } & \text { CP } \\ +++1+++ & \text { SI } & \text { NCP }\end{array}$

B.

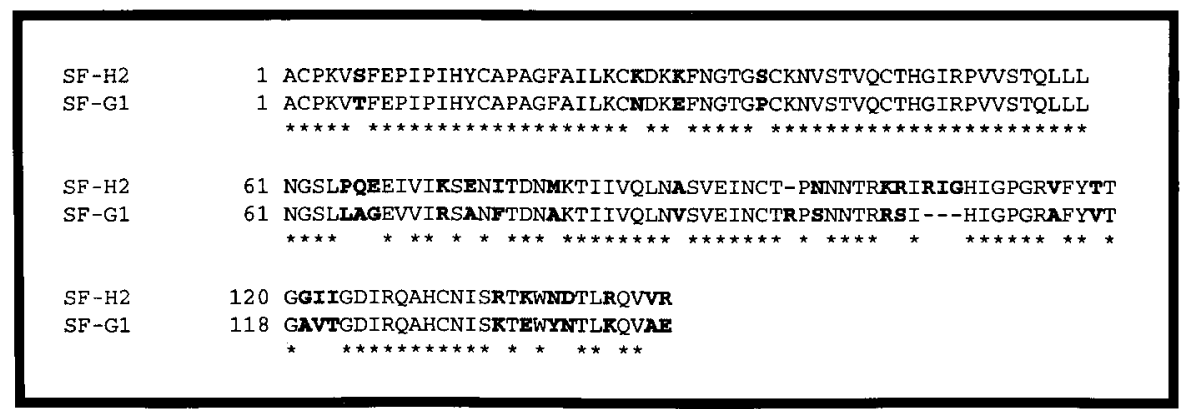

FIG. 2. Construction of chimeric viruses, SF-G1 and SF-H2. (A) A schematic representation of the chimeric cloning strategy. Chimeric viruses, SF-G1 and SF-H2, were constructed using the molecular clone, NL4-3, as the backbone. The 424-bp insert that was cloned into NL4-3 was obtained by PCR from the env gene isolated from the biological clones, HC4 and GC6 8-4, and cloned into pBluescript expression vector (p83-14 and p83-23, respectively). (B) The amino acid sequence from StuI to NheI (nucleotide position 6822 to 7250 , based on NL4-3 sequence) from env gene isolated from the biological clones, HC4 and GC6 8 4 , and cloned into pBluescript expression vector. The highlighted region shows the amino acids that are different between the two chimeric viruses, SF-G1 and SF-H2. (C) The tropism, phenotype, and cytopathic profiles of the constructs. $*+++$, viral replication in T-cell lines and/or PBMC; -, no viral replication; \# SI, syncytium-induc ing; NSI, nonsyncytium inducing; ** CP, cytopathic in T-cell lines and PBMC; NCP, noncytopathic in T-cell lines and PBMC. 

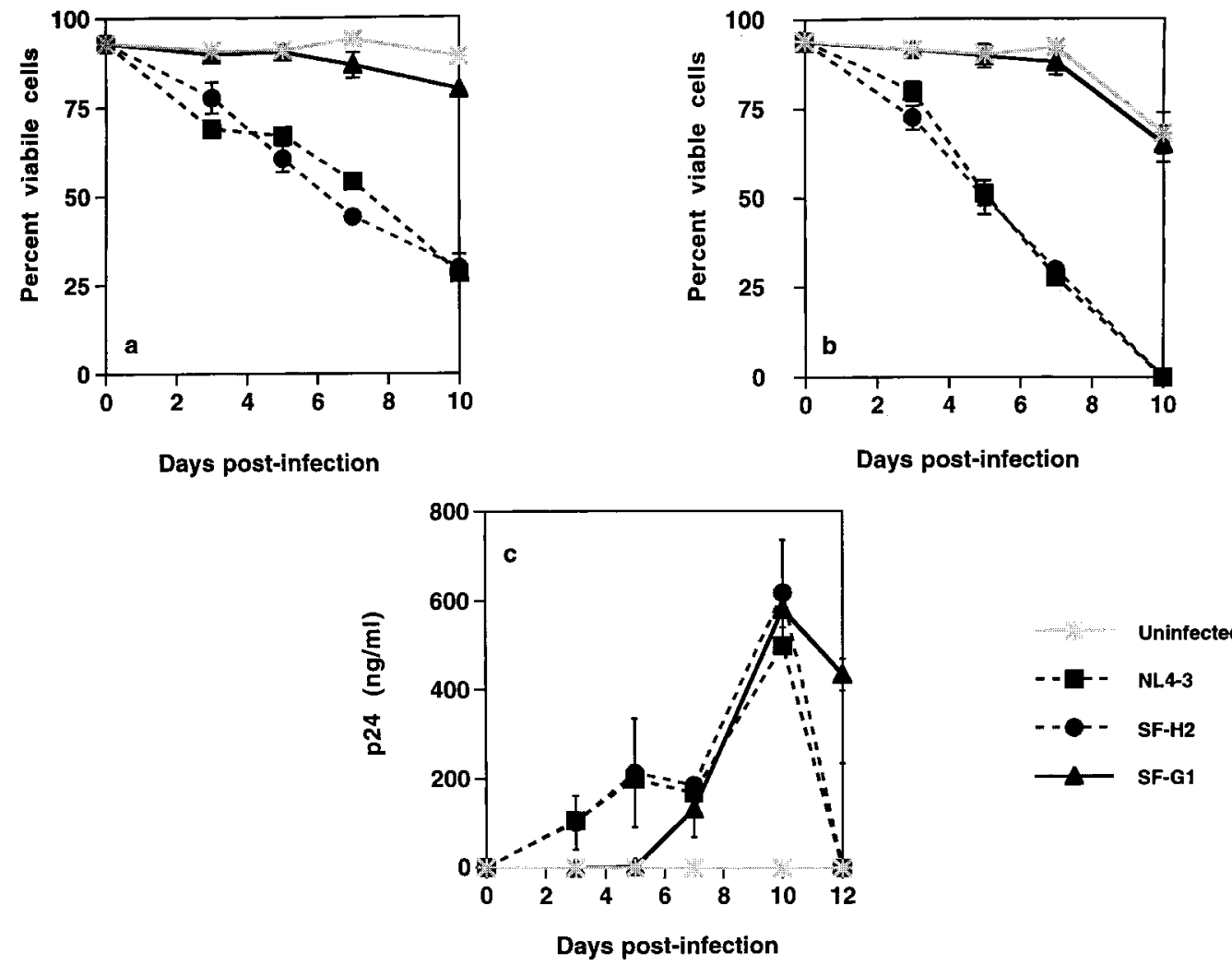

FIG. 3. Viability of PBMC and CD4-enriched T cells infected with HIV-1 chimeric viruses, SF-G1 and SF-H2. Mitogen-stimulated PBMC or CD4-enriched T cells were infected with titered chimeric viruses, SF-G1 and SF-H2, as described in Materials and Methods. Cells underwent complete media change every 2 days. Percent viable cells was calculated every 2 days by trypan blue dye exclusion. HIV-1 replication in infected PBMC and CD4 T-cell cultures was measured every 2 days by assaying cellfree culture supernatants for HIV-1 p24 gag protein using an antigen capture ELISA. Data from eight individual experiments are presented along with standard deviations. (a) Viability of PBMC infected with chimeric viruses, SF-G1 and SF-H2. (b) Viability of CD4-enriched T cells infected with chimeric viruses, SF-G1 and SF-H2. (c) Replication kinetics of chimeric viruses, SF$\mathrm{G} 1$ and SF-H2, in infected CD4-enriched $\mathrm{T}$ cells.

StuI to NheI had any effect on the phenotype of the chimeric viruses, the ability of each chimeric virus to form syncytia was measured in a standard MT-2 assay. The removal of the region from pNL4-3 between StuI to Nhe-I and replacem ent with the StuI to NheI region (Fig. 2B) from HIV-1 biological clones, HC4 and GC6 8-4, did not change the SI viral phenotype of the parental virus, NL4-3 (Fig. 2C). Both SF-G1 and SF-H2 viruses formed syncytia in MT-2 cells. This is in contrast to the previous result with the biological clone, GC6 8-4, which is NSI in MT-2 cells. ${ }^{18}$

In similar assays, the chimeric viruses SF-G1 and SF-H2, and the NL4-3 virus replicated and induced syncytia in JurkatCCR5 cells. However, NL4-3 virus and SF-H2 chimeric virus and not SF-G1 chimeric virus replicated to high titers in Jurkat cells.

\section{Infection of primary PBMC with chimeric $H I V-1$,} $S F-G 1$ and $S F-H 2$

PHA-stimulated seronegative donor PBMC were infected with HIV-1 chimeric viruses SF-H2 or SF-G1. The infection of PBMC with the two HIV-1 chimeric viruses showed notably different outcomes. The pattern of cell lysis in PBMC infected with HIV-1 chimeric virus SF-H2 virus was very similar to the control cytopathic infection with NL4-3 virus. The results were observed for six separate experiments. On day 5 postinfection, the mean percent viability of PBMC infected with HIV-1 chimeric virus SF-H2 was $60( \pm 4)$ and PBMC infected with NL4-3 was $62( \pm 16)$ (Fig. 3a). By day 10 postinfection, $70 \%$ of the PBMC were dead in the cultures infected with either the HIV-1 chimeric virus, SF-H2, or the known cytopathic molecular clone, NL4-3 (Fig. 3a). In contrast, PBMC infected with SF-G1 retained a level of viability comparable to the uninfected control cells. On day 5 postinfection, the mean percent viability of PBMC infected with SF-G1 was $90( \pm 2)$ and the uninfected control was $91( \pm 1)$ (Fig. 3a). By day 10 postinfection, the mean percent viability of uninfected PBMC or PBMC infected with SF-G1 was $90( \pm 1)$ and $80( \pm 2)$, respectively (Fig. $3 a)$.

Replication kinetics of chimeric HIV-1,SF-G1 and $\mathrm{SF}-\mathrm{H} 2$, in PBMC

The replication kinetics of both viruses were similar to each other as well as to NL4-3. There was a delay in viral p24 production by HIV-1 chimeric virus SF-G1 but this was transient 
and eventually the viral replication was equivalent to that of SF-H2 and NL4-3. These results were observed for six separate experim ents. On day 5 postinfection, the mean p24 assayed from the cultures infected with HIV-1 chimeric viruses, SF-H2 and SF-G1, was $120( \pm 119)$ and $49( \pm 94) \mathrm{ng} / \mathrm{ml}$, respectively. By day 7 postinfection, the mean $\mathrm{p} 24$ assayed from the cultures infected with HIV-1 chimeric viruses, SF-G1 and SF-H2, was $148( \pm 54)$ and $206( \pm 81) \mathrm{ng} / \mathrm{ml}$, respectively.

\section{Infection of CD4-enriched $T$ cells with chimeric $H I V-1, S F-G 1$ and SF-H2}

CD4-enriched $\mathrm{T}$ cells were infected with HIV-1 chimeric virus SF-H2 or HIV-1 chimeric virus SF-G1. The infection of CD4-enriched T cells with the two chimeric viruses showed notably different outcomes. The pattern of cell destruction in CD4enriched T cells infected with HIV-1 chimeric virus SF-H2 was very similar to the control cytopathic NL4-3 virus. On day 5 postinfection, the mean percent viability (obtained from eight separate experiments) of CD4-enriched $\mathrm{T}$ cells infected with SF-H2 was $53( \pm 2)$ and CD4 enriched T cells infected with NL4-3 was 52 ( \pm 5 ) (Fig. 3b). By day 7 postinfection, approximately $70 \%$ of the CD4-enriched T cells were dead in the cultures infected with either HIV-1 chimeric virus SF-H2 or NL43 (Fig. 3b). However, HIV-1 chimeric virus SF-G1 was phenotypically different from SF-H1. On day 5 postinfection, the mean percent viability of CD4-enriched T cells infected with HIV-1 chimeric virus SF-G1 was $89( \pm 4)$ and the uninfected control was $91( \pm 2)$ (Fig. 3b). By day 7 postinfection, approximately $90 \%$ of the CD4-enriched T cells were viable from cultures either uninfected or infected with HIV-1 chimeric virus SF-G1 (Fig. 3b).

\section{Replication kinetics of chimeric HIV-1,SF-G1 and SF-H2, in CD4-enriched T cells}

The replication kinetics of both viruses were similar to the NL4-3 virus. There was a delay in viral $\mathrm{p} 24$ production by HIV1 chimeric virus SF-G1 but this was transient and by day 7, SFG1 viral replication $(132 \pm 63 \mathrm{ng} / \mathrm{ml})$ was equivalent to that of HIV-1 chimeric virus SF-H2 (186 $\pm 18 \mathrm{ng} / \mathrm{ml})$ and NL4-3 (Fig. $3 \mathrm{c})$. By day 10 postinfection, the mean $\mathrm{p} 24$ assayed from the cultures infected with HIV-1 chimeric viruses, SF-H2 and SFG1, was $617( \pm 158)$ and $580( \pm 40) \mathrm{ng} / \mathrm{ml}$, respectively (Fig. $3 \mathrm{c}$ ). These results were observed for eight separate experiments. Viral infection was also assessed by measuring the amount of proviral DNA. Quantitative DNA PCR analysis demonstrated that the proviral copy numbers were similar in CD4-enriched T cells infected with either HIV-1 chimeric virus SF-H2 or HIV1 chimeric virus SF-G1 (data not shown).

\section{Outcome of CD4 T cells infected with chimeric HIV-1, $S F-G 1$ and $S F-H 2$}

To determine the fate of CD4-enriched T cells infected with HIV-1 chimeric viruses, SF-G1 and SF-H2, flow cytometric analyses were performed on cells removed from the infected cultures at days $3,5,7$, and 10 postinfection. The percentage of CD4 $\mathrm{T}$ cells in uninfected and HIV-1 biological clone infected cultures was determined by flow cytometry (Fig. 4). The percentage of CD4 $\mathrm{T}$ cells in HIV-1 chimeric SF-H2-infected cultures dramatically declined over 5 to 7 days postinfection. Between days 3 and 5 postinfection, CD4 T cells declined from 82 to $21 \%$ (Fig. $4 \mathrm{~d}$ ). By day 7 postinfection, the percentage of CD4 $\mathrm{T}$ cells decreased to 15 and by day 10 the culture was completely dead. In contrast, by day 5 postinfection, there was 82\% CD4 T cells in HIV-1 chimeric virus SF-G1 infected cultures (Fig. 4b), and 90\% CD4 T cells in the uninfected culture (Fig. 4a). The cells in the lower left quadrant represent viable $\mathrm{T}$ cells that have down-regulated their CD4 antigen expression due to viral infection. On day 7 postinfection, $72 \%$ of $\mathrm{T}$ cells in HIV-1 chimeric virus SF-G1 infected culture expressed CD4 antigen and $20 \%$ of viable $\mathrm{T}$ cells had down-regulated their expression of CD4 antigen.

\section{Infection of Jurkat-CCR5 cells with the chimeric viruses, SF-G1 and SF-H2}

To address the question of whether the chimeric virus, SFG1 was truly attenuated or whether the HIV-1-induce d cell lysis was delayed, we used a T-cell line, Jurkat-CCR5. One limitation with the use of CD8-depleted PBMC cultures is that the life of these cells in vitro is very short (10-12 days) compared with $\mathrm{T}$-cell lines that are adapted for culture and can be kept in culture indefinitely. Jurkat-CCR5 $\mathrm{T}$ cells were infected with HIV-1 chimeric virus SF-H2 or HIV-1 chimeric virus SF-G1. The infection of Jurkat-CCR5 $\mathrm{T}$ cells with the two chimeric viruses showed notably different outcomes. The pattern of cell destruction in Jurkat-CCR5 $\mathrm{T}$ cells infected with HIV-1 chimeric virus SF-H2 was very similar to the control cytopathic NL4-3 virus. On day 8 postinfection, the percent viability of Jurkat-CCR5 T cells infected with SF-H2 was $56 \%$ and JurkatCCR5 T cells infected with NL4-3 was $46 \%$ (Fig. 5a). The viral replication on day 8 postinfection, as measured by p24 antigen production, was equivalent for all the three viruses, NL4-3, SF-H2, and SF-G1 (186, 230, and 317 pg/ml, respectively (Fig. $5 b)$. Viral replication peaked on day 10 with cultures infected with NL4-3, (1178 ng/ml), SF-H2 (1486 ng/ml), and SF-G1 (1141 ng/ml) producing equivalent amounts of p24 antigen (Fig. $5 b)$. By day 13 postinfection, approximately $80 \%$ of the JurkatCCR5 $\mathrm{T}$ cells were dead in the cultures infected with either HIV-1 chimeric SF-H2 or NL4-3 (Fig. 5a). The cultures infected with either SF-H2 or NL4-3 were completely dead by day 17 postinfection. In contrast, infection of Jurkat-CCR5 Tcells with HIV-1 chimeric virus SF-G1 produced different results. The differences between the uninfected control and those $\mathrm{T}$ cells infected with SF-G1 were observed early in the course of the infection. Between days 8 and 15 postinfection, the viability of $\mathrm{T}$ cells infected with SF-G1 ranged from $65 \%$ (day 8 ) to $60 \%$ (day 15). During this time many syncytia were observed in the cultures infected with NL4-3, SF-H2, and SF-G1. Interestingly, on day 17 postinfection the cultures infected with SFG1 began to recover and $74 \%$ of the $\mathrm{T}$ cells were viable (Fig. $5 a)$. On day 22 postinfection, the percent viability of JurkatCCR5 T cells infected with HIV-1 chimeric virus SF-G1 was $90 \%$ as was the uninfected control (Fig. 5a). From day 20 through the end of the experiment on day 38 , the culture infected with SF-G1 continued to produce virus (figure $5 \mathrm{~b}$ ). On day 39 postinfection when the experiment was terminated, $97 \%$ of the Jurkat-CCR $5 \mathrm{~T}$ cells were viable from cultures either uninfected or infected with HIV-1 chimeric virus SF-G1 (Fig. 5a). 
Day 3

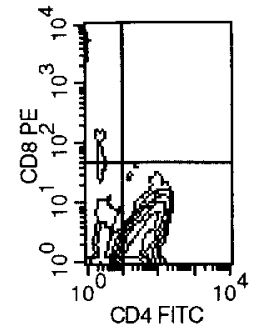

Day

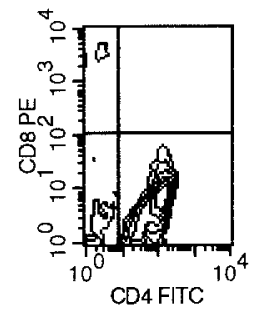

Day

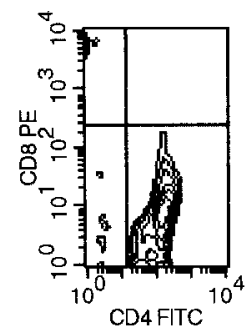

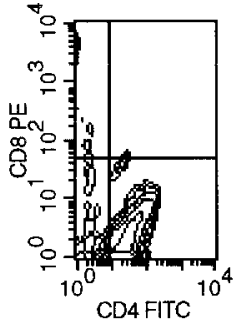
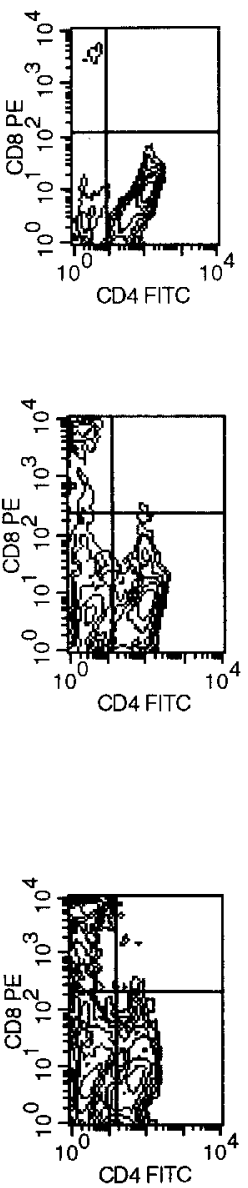
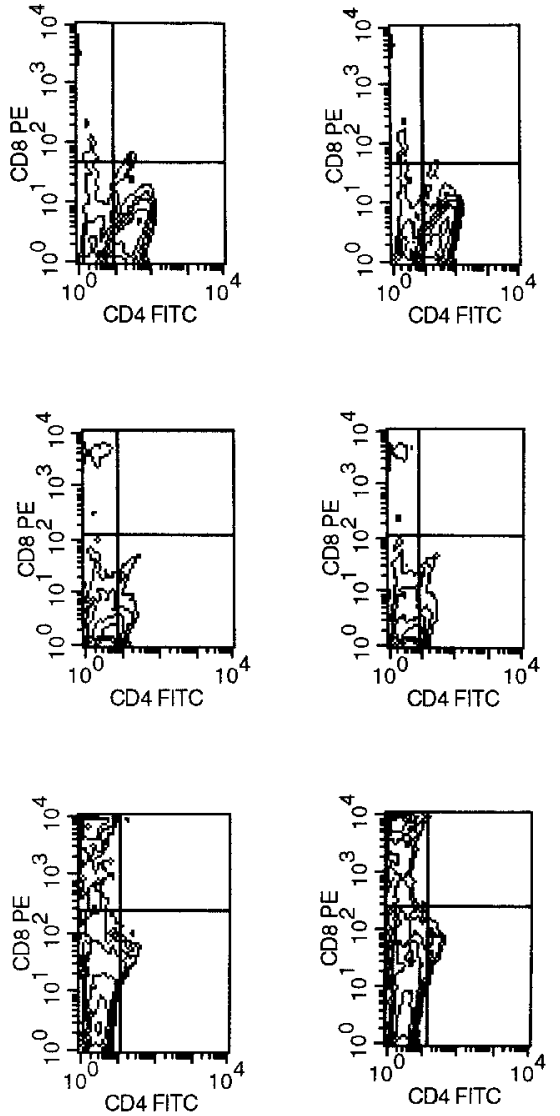

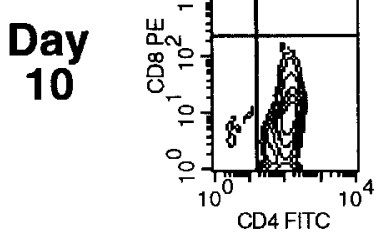

a

b

C

d

FIG. 4. CD4-enriched T cells infected with the chimeric virus, SF-G1, retain viable CD4-positive cells. Two-color flow cytometry analysis of CD4-enriched $\mathrm{T}$ cells uninfected or infected with either NL4-3 virus or chimeric viruses, SF-G1 and SF-H2. Cells were harvested on days 3, 5, 7, and 10 postinfection, stained for both CD4 and CD8, fixed in paraformaldehyde, and analyzed by flow cytometry. (a) Uninfected. (b) Chimeric virus, SF-G1. (c) Chimeric virus, SF-H2. (d) Molecular virus clone, NL4-3.

On day 24 of the infection, cell-free viral supernatant from the SF-G1 culture, now termed SF-G1R1, was used to infect new Jurkat-CCR5 T cells. Between days 3 (day 27) and 6 (day 33) postinfection, the viability of $\mathrm{T}$ cells reinfected with SF-G1R1 ranged from $75 \%$ (day 29) to $60 \%$ (day 33) (Fig. 5a). During this period many syncytia were observed in the cultures. Interestingly, on day 7 postinfection with SF-G1R1 the infected cultures began to recover and $75 \%$ of the $\mathrm{T}$ cells were viable (SF-
G1R1, Fig. 5a). On day 13 postinfection, the percent viability of Jurkat-CCR5 $\mathrm{T}$ cells reinfected with HIV-1 chimeric virus SF-G1 was $89 \%$ (SF-G1R1, Fig. 5a).

\section{DISCUSSION}

In this study we genetically analyzed a specific region within HIV-1 envelope (nucleotide positions 6822 to 7250 ) from a cy- 

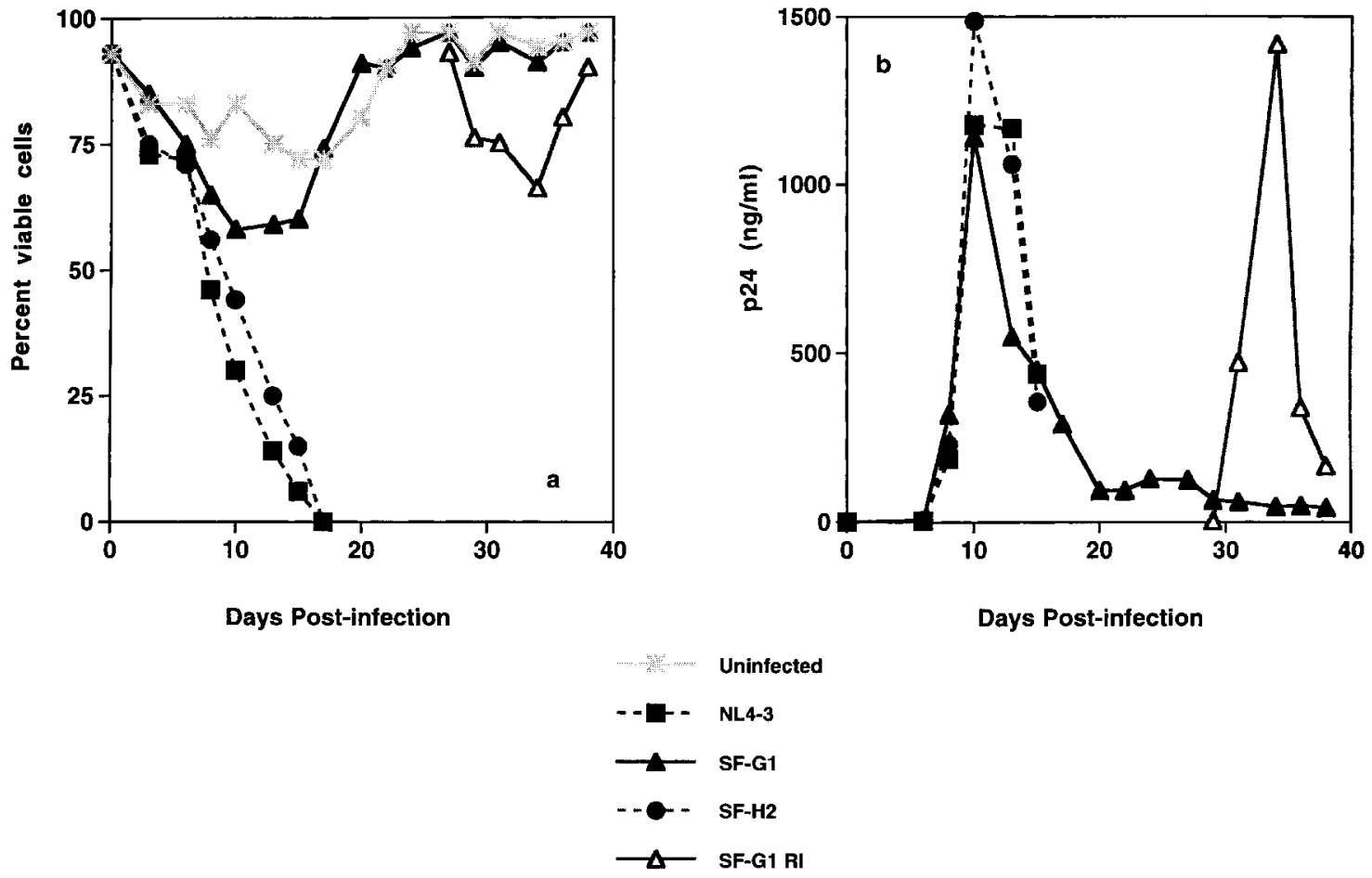

FIG. 5. Viability of Jurkat-CCR5 cells infected with HIV-1 chimeric viruses, SF-G1 and SF-H2. Jurkat-CCR5 cells were infected with titered chimeric viruses, SF-G1 and SF-H2, as described in Materials and Methods. Cells underwent complete media change every 2 days. On day 24 of the infection, cell-free viral supernatant from the SF-G1 culture, now termed SF-G1R1, was used to infect fresh Jurkat-CCR5 cells. Percent viable cells was calculated every 2 days by trypan blue dye exclusion. HIV1 replication in infected Jurkat-CCR5 cultures was measured every 2 days by assaying cell-free culture supernatants for HIV-1 p24 gag protein using an antigen capture ELISA. Data from one representative experiment are presented. (a) Viability of JurkatCCR5 cells infected with chimeric viruses, SF-G1 and SF-H2. On day 24 of the infection, cell-free viral supernatant from the SF-G1 culture, now termed SF-G1R1, was used to infect fresh Jurkat-CCR5 cells. (b) Replication kinetics of chimeric viruses, SF-G1 and SF-H2, in Jurkat-CCR5 T cells.

topathic and a noncytopathic biological clone by generating chimeric viruses with the well-characterized molecular clone, NL4-3. The most striking difference between these chimeric viruses when compared to each other as well as NL4-3 was that SF-G1, the chimeric virus containing a downstream V2 and V3 region of the noncytopathic envelope, was attenuated for cytopathicity. This switch in cytopathicity held true in PBMC as well as in T-cell lines (Figs. 3 and 5).

In general, viruses that infect macrophages are restricted in their ability to infect T-cell lines. It has been shown that viruses isolated early in infection are NSI and macrophage tropic, while viruses recovered from individuals with low CD4 T-cell counts are generally SI with the ability to replicate in T-cell lines. ${ }^{1-4}$ When the phenotype of each chimeric virus was assessed it was found to be identical to the parental virus NL4-3, which is SI. The chimeric viruses, SF-G1 and SF-H2, were both SI despite different V3 signature sequences that predicted that SF-G1 would be NSI and SF-H2 would be SI. The V 3 region sequenced from SF-H2 has classic SI hallmarks, such as increased charge $\left({ }^{+} 7\right.$, Fig. 1B $)$ and a switch from an arginine at position 11 along with a switch to glycine at position 25 (Fig. 1B). The predicted phenotype based solely on the V3 sequence of SF-H2 is SI. The results are in agreement with this prediction (Fig. 2C). At all stages in the viral population, i.e., quasispecies, ${ }^{17}$ biological clone, ${ }^{18}$ and chimeric virus (this report), the predicted phenotype was the determined phenotype. In contrast, the V3 region sequenced from SF-G1 showed features attributed to viruses having an NSI phenotype, such as an overall change of ${ }^{+} 5$ with an alanine at position 25 of the V3 loop (Fig. 1B). Therefore, the predicted phenotype, based solely on the V3 sequence of SF-G1, was NSI. SF-G1 chimeric virus replicated to high titers in Jurkat-CCR5 $\mathrm{T}$ cells and not in Jurkat $\mathrm{T}$ cells. The phenotype of the patient A quasispecies was $\mathrm{NSI}^{17}$ as was the phenotype of the biological clone isolated from the quasispecies. ${ }^{18}$ Although the chimeric clone SF-G1 preferentially used the CCR 5 coreceptor the phenotype of the SF-G1 virus was SI (Fig. $2 \mathrm{C})$. These results contrast with previous published observations ${ }^{30,31}$ that show that mutations within the envelope gene (gp120), allowing an SI phenotype, are capable of increasing cytopathicity. However, these data are consistent with the recent published observation in the SIV system. ${ }^{1}$ Kimata and Overbaugh showed that the minimal region of SIV responsible for syncytium formation mapped to the envelope gene. ${ }^{52}$ Even though the phenotype of the chimeric SIV env was SI it did not increase the cytopathicity in either $\mathrm{CEM} \times 174$ or macaque PBMC. Other variable regions besides V3 have been suggested to play a role in HIV cytopathicity. It has been shown that envelope glycoproteins that contain either site-directed mutations 
within the $\mathrm{V} 1 / \mathrm{V} 2$ region ${ }^{43,44}$ or $\mathrm{V} 1 / \mathrm{V} 2$ regions containing chimeric V2 sequences exhibit altered cytopathicity. ${ }^{45-47}$ Sullivan and co-workers demonstrated that specific amino acids mutations in the tip of V2 yielded fusion defective viruses. ${ }^{44}$ In addition, all of the mutant V1/V2 envelope glycoproteins displayed decreased syncytium-inducing abilities, with some mutants lacking the ability to induce cell fusion altogether. Taken together, these results demonstrate that the third variable region of envelope is not the only region involved in syncytium formation. Moreover, the formation of syncytium does not necessarily dictate cell death (Fig. 5). In other words, the NSI/SI phenotype does not correlate with the NCP/CP phenotype. These results further support previous observations that HIV-1-induced single cell killing is independent of syncytium formation. ${ }^{48}$

Differences in HIV-1 viral tropism, phenotype, and replication kinetics have been assigned to the envelope surface glycoprotein. ${ }^{30,31}$ Along with these properties, studies of mutant HIV-1 viruses have provided evidence that a major determinant for cell killing maps to the viral envelope glycoproteins. For these reasons, prior to analyzing these subgenomic fragments, we attempted to construct full-length env chimeric viruses by replacing the env region from NL4-3 with either the HC4 or GC6 8-4 env gene. The many attempts using standard cloning techniques, in vitro recombination, and advanced cloning techniques failed to develop a stable full length functional envelope product. For reasons we can not explain, envelope genes isolated from these biological clones are extremely unstable.

The molecular mechanism(s) of HIV-1-induced cell lysis is likely to be multifactorial. Experiments with mutant HIV-1 viruses do not unequivocally resolve the role of viral accessory proteins (Vif, Vpr, Tat, Nef) in HIV-1 cell killing. ${ }^{49-51}$ ChengMayer and colleagues concluded from their observations with recombinant viruses that the envelope region contains the major determinants of HIV-1 cytopathicity. ${ }^{32}$ Stevenson et al. ${ }^{34}$ reported that two amino acid changes within gp120 altered the efficiency of processing of the gp160 envelope glycoprotein precursor, which in turn decreased the ability of a replicationcompetent HIV-1 virus to induce single cell lysis. Kowalski et al. ${ }^{33}$ showed that a mutation within the gp41 amino terminus of envelope, which generated a replication-com petent noncytopathic virus, was attenuated in its ability to form syncytia and to induce single cell death. Cao et al. ${ }^{35}$ described an inducible system to examine envelope-induced single cell lysis. Their studies demonstrated that the ability of HIV-1 envelope glycoproteins to mediate membrane fusion was obligatory for both syncytium formation and single cell lysis.

Our results demonstrate that the cytopathic profile of NL43 can be altered by a specific disruption of the envelope sequences contained within the downstream region of $\mathrm{V} 2$ and within the V3 region (nucleotide positions 6822 to 7250). Interestingly, disrupting this region by inserting the same region from a cytopathic biologically cloned virus (HC4) did not alter the ability of the parental virus to induce cell death (Fig. 2). It was only when that region was disrupted with the insertion of the same region from a noncytopathic biologically cloned virus (SF-G1) did the cytopathic profile change (Fig. 2). These results suggest that it is not just the disruption of that region but the disruption of that region by a specific sequence, which attenuates the cytopathic profile of the parental virus. The pre- cise role of these specific sequences in cytopathicity and coreceptor usage will be further analyzed using detailed mutagenesis studies that are underway.

Cao et al. ${ }^{35}$ and others ${ }^{31-34}$ have shown that differences in HIV-1 cytopathicity can be mapped to mutations within the envelope glycoproteins. Recent observations regarding SIV-induced cytopathicity have reached similar conclusions. Kimata and Overbaugh ${ }^{52}$ showed that SIV-induced cytopathicity is determined by mutations in $g a g$ and $e n v$ genes. Karlsson et al. ${ }^{53}$ using passaged recombinant SHIV-89.6P viruses constructed between SIV (SIV $\operatorname{mac}_{239}$ ) and HIV-1 (89.6) showed that changes within the $3^{\prime}$ half of the SHIV-89.6P genome that occurred within the envelope gene were responsible for increased cytopathicity. Taken together, these findings, along with those reported herein, support the hypothesis that the HIV-1 envelope glycoprotein plays a role in HIV-1-induced cytopathicity. Further studies addressing the role of envelope in HIV-1-induced cell killing are necessary to understand the specific molecular mechanism(s) involved in CD4 T-cell depletion in AIDS pathogenesis.

\section{ACKNOWLEDGMENTS}

We thank Drs. Mario Stevenson, Katherine Luzuriaga, Ron Desrosiers, and Susanna Lamers for valuable discussions and their critical review of the manuscript.

This work was supported in part by grants from the National Institutes of Health (AI 32907, AI 39400, and AI 26507).

\section{REFERENCES}

1. Asjo B, Morfeldt-Manson L, Albert J, Biderfield G, Karlsson A, Lidman K, and Fenyo EM: Replicative capacity of human immunodeficiency virus from patients with varying severity of HIV infection. Lancet 1986:ii:660-662.

2. Cheng-Meyer C, Seto D, Tateno M, and Levy JA: Biologic features of HIV-1 that correlate with virulence in the host. Science 1988;240:80-82.

3. Fenyo EM, Morfeldt-Man son L, Chiodi F, Lind A, von Gegerfelt A, Albert J, Olausson E, and Asjo B: Distinct replicative and cytopathic characteristics of human immunodeficie ncy virus isolates. J Virol 1998;62:4414-4419.

4. Tersmette M, Gruters RA, de Wolf F, de Goede RY, Lange JMA, Schellekens PT, Goudsmit J, Huisman HG, and Miedema F: Evidence for a role of virulent human immunodeficie ncy virus (HIV) variants in the pathogenesis of acquired immunodeficiency syndrome: Studies on sequential HIV isolates. J Virol 1989;63: 2118-2125.

5. Feng Y, Broger CC, Kennedy PE, and Berger EA: HIV-1 entry cofactor: Functional cDNA cloning of a seven-transmembrane, Gprotein-coupled receptor. Science 1996;272:872-877.

6. Choe H, Farzan M, Sun Y, Sullivan N, Rollins B, Ponath PD, Wu L, Mackay CR, LaRosa G, Newman W, Gerard N, Gerard C, and Sodroski J: The $\beta$-chemokine receptors CCR3 and CCR5 facilitate infection by primary HIV-1 isolates. Cell 1996;85:1135-1148.

7. Deng H, Liu R, Ellmeier W, Choe S, Unutmaz D, Burkhart M, Di Marzio P, Marmon S, Sutton RE, Hill CM, Davis CB, Peiper SC, Schall TJ, Littman DR, and landau NR: Identification of a major co-receptor for primary isolates of HIV-1. Nature (London) 1996; 381:661-666. 
8. Doranz BJ, Rucker J, Yi Y, Smyth RJ, Samson M, Peiper SC, Parmentier M, Collman RG, and Doms RW: A dual-tropic primary HIV- 1 isolate that uses fusin and the $\beta$-chemokine receptors CKR5, CKR-3, and CKR-2b as fusion cofactors. Cell 1996;85: 1149-1158.

9. Dragic T, Litwin V, Allaway GP, Martin SR, Huang Y, Nagashima KA, Cayanan C, Maddon PJ, Koup RA, Moore JP, and Paxton WA: HIV-1 entry into CD4+ cells is mediated by chemokine receptor CC-CKR-5. Nature (London) 1996;381:667-673.

10. Simmons G, Wilkinson D, Reeves JD, Dittmar MT, Beddows S, Weber J, Carnegie G, Desselberger U, Gray PW, Weiss RA, and Clapham PR: Primary, syncytium-induc ing human immunodeficiency virus type 1 isolates are dual-tropic and most can use either of CCR5 coreceptors for virus entry. J Virol 1996;70:8355-8360.

11. Fauci AS: The human immunodeficiency virus: Infectivity and mechanisms of pathogenesis. Science 1988;239:617-622.

12. Fauci AS: Multifactorial nature of human immunodeficien cy virus disease: Implications for therapy. Science 1993;262:1011-1018.

13. Groenink M, Fouchier RAM, de Goede REY, de Wolf F, Cuypers HTM, Gruters RA, Husiman HG, and Tersmette M: Phenotypic heterogeneity in a panel of infectious molecular human immunodeficiency virus type 1 clones derived from a single individual. J Virol 1991;65:1968- 1975.

14. Roos MTL, Lange JMA, de Goede REY, Coutinho RA, Schellekens PTA, Miedema F, and Tersmette M: Viral phenotype and immune response in primary human immunodeficie ncy virus type 1 infection. J Infect Dis 1992;165:427-432.

15. Schuitemaker H, Koot M, Kootstra NA, Wouter D, de Goede REY, vanSteenwijk RP, Lange JMA, Eeftink-Schattenkerk JKM, Miedema F, and Tersmette M: Biological phenotype of human immunodeficiency virus type 1 clones at different stages of infection: Progression of disease associated with a shift from monocytotropic to T-cell tropic virus populations. J Virol 1992;66:1345-1360.

16. Tersmette M, de Goede REY, Al BJM, Winkel IN, Gruters RA, Cuypers HTM, Huisman HG, and Miedema F: Differential syncytium-inducing capacity of human immunodeficiency virus isolates: Frequent detection of syncytium-induc ing isolates in patients with acquired immunodeficie ncy syndrome (AIDS) and AIDS-related complex. J Virol 1988;62:2020-2032.

17. Forte SE, Byron KS, Sullivan JL, and Somasundaran M: Non-syncytium inducing HIV-1 isolated from infected individuals replicate in MT-2 cells. AIDS Res Hum Retroviruses 1994;10:1613-1619.

18. Forte SE, Sullivan JL, and Somasundaran M: In vitro characterization of HIV type 1 biological clones from asymptomatic and symptomatic pediatric patients. AIDS Res Hum Retroviruses 1996;12:1585- 1593.

19. Dickover R, Dillon M, Gillette S, Deveikis A, Keller M, PlaegerMarshall S, Chne I, Diagne A, Stiehm ER, and Bryson Y: Rapid increase in load of human immunodeficiency virus correlate with early disease progression and loss of CD cells in vertically-infected infants. J Infect Dis 1994;170:1279- 1284.

20. Auger I, Thomas P, de Gruttola V, Morse D, Moore D, Williams $\mathrm{R}$, Truman B, and Lawrence CE: Incubation periods for pediatric AIDS patients. Nature (London) 1988;336:575-577.

21. Bryson YJ, Luzuriaga K, Sullivan JL, and Wara DW: Proposed definitions for in utero versus intrapartum transmission of HIV-1 (letter). N Engl J Med 1992;327:1246- 1247.

22. Alimenti A, Luzuriaga K, Stechenberg B, and Sullivan JL: Quantitation of human immunodeficiency virus in vertically infected infants and children. J Pediatr 1991;119:225-229.

23. Connor RI, Mohri H, Cao Y, and Ho DD: Increased viral burden and cytopathicity correlate temporally with CD4+ T-lymphocyte decline and clinical progression in human immunodeficie ncy virus type 1-infected individuals. J Virol 1993;67:1772- 1777.

24. De Rossi A, Giaquinto C, Ometto L, Mammano F, Zanotto C, Dunn $\mathrm{D}$, and Chieco-Bianco L: Replication and tropism of human immu- nodeficiency virus type 1 as predictors of disease outcome in infants with vertically-acquired infection. J Pediatr 1993;123:929-936.

25. Spencer LT, Ogino MT, Danker WM, and Spector SA: Clinical significance of human immunodeficiency virus type 1 phenotype in infected children. J Infect Dis 1994;169:491-495.

26. Tersmette M, Lange J, de Goede R, Wolf F, Eeftink-Shatten kerek J, Shellekens P, Coutinho RA, Huisman H, Goudsmit J, and Miedema F: Association between biological properties of human immunodeficie ncy virus variants and risk for AIDS and AIDS mortality. Lancet 1989;i:983-985.

27. Luzuriaga K, Holmes D, Hereema A, Wong J, Panicalli DL, and Sullivan JL: HIV-1 Specific cytotoxic T lymphocyte responses in the first year of life. J Immunol 1995;154:433-443.

28. Luzuriaga K, Koup RA, Pikora CA, Brettler DB, and Sullivan JL: Deficient human immunodeficiency virus type 1-specific cytotoxic $\mathrm{T}$ cell responses in vertically infected children. J Pediatr 1991; 119:230-236.

29. Plaeger-Marshall S, Hultin, P, Bertolli J, OíRourke S, Kobayashi R, Kobayashi AL, Giorgi JV, Bryson Y, and Stiehm ER: Activation and differentiation antigens on $\mathrm{T}$ cells of healthy, at-risk and HIV-1 infected children. J Acquir Immune Defic Syndr 1993;6: 984-993.

30. Cheng-Meyer C, Shido T, and Levy JA: Host range, replicative, and cytopathic properties of human immunodeficiency virus type 1 are determined by very few amino acid changes in tat and gp120. J Virol 1991;65:6931-6941.

31. de Jong JJ, Goudsmit J, Keulen W, Klaver B, Krone W, Tersmette $\mathrm{M}$, and de Ronde A: Human immunodeficiency virus type 1 clones chimeric for the envelope V3 domain differ in syncytium formation and replication capacity. J Virol 1992;66:757-765.

32. Chang-Meyer C, Quiroga M, Tung JW, Dina D, and Levy J: Viral determinants of human immunodeficiency virus type $1 \mathrm{~T}$-cell or macrophage tropism, cytopathogenicity, and CD4 antigen modulation. J Virol 1990;64:4390-4398.

33. Kowalski M, Bergeron L, Dorfman T, Haseltine W, and Sodroski $\mathrm{J}$ : Attenuation of human immunodeficie ncy virus type 1 cytopathic effect of a mutation affecting the transmembrane envelope glycoprotein. J Virol 1991;65:281-291.

34. Stevenson M, Haggerty S, Lamonica C, Mann AM, Meier C, and Wasiak A: Cloning and characterization of human immunodeficiency virus type 1 variants diminished in the ability to induce syncytium-indepen dent cytolysis. J Virol 1990;64:3792-3803.

35. Cao J, Park I-W, Cooper A, and Sodroski J: Molecular determinants of acute single-cell lysis by human immunodeficiency virus type 1. J Virol 1996;70:1340-1354.

36. Myers G: Human Retroviruses and AIDS. Los Alamos National Laboratory, 1993.

37. Lamers SL, Sleasman JW, and Goodenow MM: A model for alignment of env V1 and V2 hypervariable domains from human and simian immunodeficiency viruses. AIDS Res Hum Retroviruses 1996;12:1169- 1178 .

38. Gibbs JS, Reiger DA, and Desrosiers RC: Construction and in vitro properties of HIV-1 mutants with deletions in nonessential genes. AIDS Res Hum Retroviruses 1994;10:343-350.

39. Koot M, Vos AHV, Keet RPM, de Goede RY, Dercksen MW, Terpstra FG, Coutinho RA, Meidema F, and Tersmette M: HIV-1 biological phenotype in long-term infected individuals evaluated with an MT-1 cocultivation assay. AIDS 1991;6:49-54.

40. Saiki RK, Gelfand DH, and Stoffel S: Primer directed enzymatic amplification of DNA with a thermostable DNA polymerase. Science 1988;239:487-491.

41. Zhong P, Peeters M, Janssens W, Fransen K, Heyndrickx L, Vanham G, Willems B, Piot P, and van der Groen G: Correlation between genetic and biological properties of biologically clones HIV type 1 viruses representing subtypes A, B, and D. AIDS Res Hum Retroviruses 1995;11:239-248. 
42. Mammano F, Salvatori F, Ometto L, Panozzo M, Chieco-Bianchi L, and De Rossi A: Relationship between the V3 loop and phenotypes of human immunodeficiency virus type 1 (HIV-1) isolates from children perinatally infected with HIV-1. J Virol 1995;69: 82-92.

43. Boyd MT, Simpson GR, Cann AJ, Johnson MA, and Weiss RA: A single amino acid substitution in the V1 loop of human immunodeficiency virus type $1 \mathrm{gp} 120$ alters cellular tropism. J Virol J 1993;67:3649-3652.

44. Sullivan N, Thali M, Furman G, Ho DD, and Sodroski J: Effect of amino acid changes in the V1/V2 region of the human immunodeficiency virus type 1 gp120 glycoprotein on subunit association, syncytium formation, and recognition by a neutralizing antibody. J Virol 1993;67:3764-3679.

45. Andeweg AC, Leeflang P, Osterhaus AD, and Bosch ML: Both V2 and $\mathrm{V} 3$ regions of the human immunodeficie ncy virus type 1 surface glycoprotein functionally interact with other envelope regions in syncytium formation. J Virol 1993;3232-3239.

46. Fred EO and Martin MA: Evidence for a functional interaction between the V1/V2 and C4 domain of human immunodeficie ncy virus type 1 envelope glycoprotein gp120. J Virol 1994;68:2503-2512.

47. Koito A, Harowe MG, Levy JA, and Cheng-Meyer C: Functional role of the V1/V2 region of human immunodeficiency virus type 1 envelope glucoprotein gp120 in infection of primary macrophages and soluble CD4 neutralization. J Virol 1994;68:2253-2259.

48. Somasundaran M and Robinson HL: A major mechanism of human immunodeficiency virus-induced cell killing does not involve cell fusion. J Virol 1987;61:3114-3119.
49. Dayton AI, Sodroski JG, Rosen CA, Goh WC, and Haseltine WA: The transactivator gene of the human T-cell lymphotropic virus type III is required for replication. Cell 1986;44:941-947.

50. Rogel ME, Wu LI, and Emerman M: The human immunodeficiency virus type $1 \mathrm{Vpr}$ arrests the cell cycle in $\mathrm{G} 2$ by inhibiting the activation of p34cdc2-cyclin B. J Virol 1995;69:6859-6864.

51. Sodroski J, Goh WC, Rosen CA, Tartar A, Portelle D, Burny A, and Haseltine WA: Replicative and cytopathic potential of human T-lyphotropic virus type III (HTLV-III/LAV) with sor gene deletions. Science 1986;240:1549-1553.

52. Kimata JT and Overbaugh J: The cytopathicity of a simian immunodeficiency virus Mne variant is determined by mutations in gag and env. J Virol 1997;71:7629-7639.

53. Karlsson GB, Halloran M, Li J, Park I, Gomila R, Reiman KA, Axthelm MJ, Iliff SA, Letvine NL, and Sodroski J: Characterization of molecularly cloned simian-human immunodeficiency viruses causing rapid CD4+ lymphocyte depletion in rhesus monkeys. J Virol 1997;71:4218-4225.

Address reprint requests to: John L. Sullivan Department of Pediatrics University of Massachusetts Medical School 373 Plantation Street Worcester, Massachusetts 01605

E-mail: john.sullivan@u massmed.edu 